\title{
PHENOLIC CONTENT AND ANTIOXIDANT CAPACITY OF POMACE AND CANES EXTRACTS OF SOME VITIS VINIFERA VARIETIES CULTIVATED IN ROMANIA
}

\author{
MIRELA L. MOLDOVAN ${ }^{1}$, CĂTĂLINA BOGDAN ${ }^{1 *}$, SONIA IURIAN $^{1}$, CECILIA ROMAN $^{2}$, \\ ILIOARA ONIGA $^{1}$, DANIELA BENEDEC ${ }^{1}$ \\ 1 "Iuliu Haţieganu” University of Medicine and Pharmacy, Faculty of Pharmacy, 12 Ion Creangă Street, 400010, Cluj- \\ Napoca, Romania \\ ${ }^{2}$ National Institute for Research-Development for Optoelectronics INOE 2000, Cluj-Napoca Branch, Romania
}

*corresponding author: catalina.bogdan@umfcluj.ro

Manuscript received: January 2019

\begin{abstract}
The by-products of winemaking processes still contain important amounts of active compounds. The aim of this study was to obtain and to characterise the chemical composition and antioxidant activity of different extracts from by-products of the wine industry: pomace and canes. Three red varieties of Vitis vinifera cultivated in Romania were used, Mamaia, Cabernet Sauvignon and Fetească neagră. Aqueous and ethanolic solutions (50\% and $70 \%)$ were prepared by hot, cold or ultrasonic extraction, as well as macerates in glycerol. The results showed that the phenolic amount in the extracts varied as follows: hot ethanol extract > cold ethanol extract > ultrasonic ethanol extract > glycerol macerate > hot water extract > ultrasonic water extract. These preliminary findings showed quantitative differences between the prepared extracts and emphasized the importance of the extraction method and the type of raw material in order to obtain the highest content of polyphenolic antioxidant compounds.
\end{abstract}

\section{Rezumat}

Sub-produsele rezultate în urma procesului de obținere a vinului conțin o cantitate importantă de principii active. Scopul acestui studiu a fost de a obține diferite extracte din tescovină și coarde - subproduse din industria vinului și de a determina compoziția chimică și activitatea antioxidantă. Au fost utilizate 3 varietăți de Vitis vinifera cultivate în România: Mamaia, Cabernet Sauvignon şi Fetească neagră. S-au preparat extracte apoase și etanolice $(50 \%, 70 \%)$ prin extracție la cald, la rece și prin sonicare, precum și macerate glicerinice. Cantitățile de compuşi fenolici au variat astfel: extract etanolic preparat la cald > extract etanolic preparat la rece $>$ extract etanolic preparat cu ultrasunete $>$ macerat glicerinic $>$ extract apos preparat la cald > extract apos preparat cu ultrasunete. Rezultatele obținute au arătat că există diferențe cantitative între extractele prepara te și au subliniat importanța metodei de extracție și a tipului de materie primă pentru obținerea de extracte cu conținut ridicat de compuși polifenolici antioxidanți.

Keywords: Vitis vinifera varieties, pomace, canes, polyphenols

\section{Introduction}

Vitis vinifera L., grapevine (Vitaceae family), is one of the oldest crop plants, being known since antiquity as the source of grapes, both for direct consumption of the fruit and for fermentation to produce wine [7]. The medicinal parts of grape vine (fruits, leaves) revealed multiple uses in dietary, medicinal, and industrial fields. Numerous studies have reported that Vitis vinifera extracts have anti-inflammatory, antimicrobial, antioxidant, anti-atherosclerotic, and antitumour or cytoprotective properties [13, 14]. In the cosmetic field, grape-derived ingredients are reported to have many functions such as flavouring, skin conditioning agents, antioxidants, anti-irritative, depigmentation agents, emollients, antimicrobial and oral care agents. Recently, wine-making by-products are subject to intensive research, knowing that over $70 \%$ of the polyphenols remain in the pomace. These wine byproducts (e.g. pomace, canes, seeds), are generally intended for the preparation of soil fertilizers and for livestock feeds, but the active principles (polyphenols, stilbene, etc.) from by-products have a high potential for human health $[9,15,18,19]$. Grape pomace, the winery waste resulted during the production of juice, is composed of skin, stem, residual pulp and seeds. Based on its phytochemical content, modern biological studies reported that the pomace and canes have antioxidant, anti-inflammatory, cardio-protective, antifungal activity, suggesting the winery-derived grape pomace as an interesting source for natural antioxidants with application in pharmacological, cosmetic and food industries [2, 7-9, 12, 20]. The studies related to the potential valorisation of winery wastes and byproducts focused mostly on the antioxidant bioactive compounds. Their concentration in the extract is greatly 
FARMACIA, 2020, Vol. 68, 1

influenced by the plant matrix, the extraction technology and extraction parameters. The conventional extraction methods using aqueous or ethanolic solvents, with or without temperature influence, are frequently used, due to the affordability and ease of use. Of modern methods, the ultrasound-assisted extraction (UAE) uses the ability of ultrasounds to produce cavitation phenomena that generate cell wall damage and content release. The recovery of active ingredients from plant products requires minimal solvent consumption, short extraction time and it is applicable as well to thermosensitive products $[3,20]$. The aim of the present study was to evaluate the chemical composition and antioxidant activity of different extracts from byproducts of the wine industry: pomace and canes in order to choose the most appropriate plant matrix and extraction parameters to obtain extracts with potential cosmetic applications.

\section{Materials and Methods}

Plant materials consisted of pomace and canes of three Vitis vinifera varieties identified by biologist A. Tănase and harvested from the experimental fields of Research Centre for Viticulture and Oenology Murfatlar, Romania (2017): Fetească neagră 9MF (4410'49,73’N; 28²5'28,67’E), Cabernet Sauvignon

$\left(44^{\circ} 10^{\prime} 49,79^{\prime \prime} \mathrm{N} ; 28^{\circ} 25^{\prime} 33,557^{\prime} \mathrm{E}\right)$, Mamaia (4410' $\left.39,55^{\prime \prime} \mathrm{N} ; 28^{\circ} 25^{\prime} 37,70^{\prime \prime} \mathrm{E}\right)$. Grape pomace was dried, then it was aerated by palletizing to remove water and avoid the development of microorganisms each $24 \mathrm{~h}$. The plant material was reduced to a powder of a proper degree of fineness [22]. Extracts from Mamaia variety pomace were first prepared according to a screening experimental design that aimed to assess the influence of extraction method and ethanol concentration on the polyphenolic content and antioxidant activity. The full factorial design was developed using Modde 12.1 software, included one qualitative factor, the extraction method, with two levels (heat reflux and ultrasonic method) and the ethanol concentration as the quantitative factor, that varied on three levels $(0 \%, 50 \%$ or $70 \%)$. The design matrix included 6 experiments and 3 centre points (Table I).

Starting from the experimental design, 9 different extracts were prepared from each of the plant products: Mamaia pomace (MP), Cabernet Sauvignon pomace (CSP), Fetească neagră pomace (FNP) and Fetească neagră canes (FNC), as it follows: powdered plant material was subjected to extraction with different solvents, using a simple maceration process (cold extraction), heat reflux and ultrasonic extraction $[5$, 22-25].

Table I

Experimental design matrix

\begin{tabular}{|c|c|c|c|c|}
\hline Exp. No. & Exp. Name & Run Order & Extraction method (X1) & Ethanol concentration (X2) \\
\hline 1 & WH & 1 & Heat & 0 \\
\hline 2 & WU & 2 & Ultrasound & 50 \\
\hline 3 & EH50 & 7 & Heat & 50 \\
\hline 4 & EU50 & 4 & Ultrasound & 70 \\
\hline 5 & EH70 & 5 & Heat & 70 \\
\hline 6 & EU70 & 6 & Ultrasound & 50 \\
\hline 7 & EH50_1 & 3 & Heat & 50 \\
\hline 8 & EH50_2 & 9 & Heat & 50 \\
\hline 9 & EH50_3 & 8 & Heat & \\
\hline
\end{tabular}

Cold extraction $(C)$ : Extracts were obtained by maceration at room temperature, for 10 days; the ratio of plant material to solvent was 1:10 [22]. Tinctures: the plant materials were extracted with ethanol $(50 \%, 70 \%)$ according to the method described in Romanian Pharmacopoeia: EC50 and EC70, respectively [22]. The macerate in a mixture of ethanol:glycerol:water (M, 50:25:25); first, the plant materials were extracted with $90 \%$ ethanol, for 4 days, then the 1:1 mixture of glycerol and water was added. The extraction was made by maceration during 6 days, followed by filtration [24, 25].

Heat reflux extraction $(H)$ : plant material powder was extracted with different solvents: ethanol (E, 50\%, $70 \%$ ) and water $(\mathrm{W})$ at $60^{\circ} \mathrm{C}$. The samples were centrifuged, and the supernatants were recovered: EH50, EH70 and WH [1, 22, 23].
Ultrasonic extraction $(U)$ : plant material powder was extracted with different solvents: ethanol $(50 \%, 70 \%)$ and water, on ultrasonic bath at $40^{\circ} \mathrm{C}$, for $30 \mathrm{~min}$ [5]. Chemicals: gallic acid, rutin, caffeic acid, FolinCiocâlteu reagent, sodium carbonate, sodium nitrite, sodium molybdate, sodium hydroxide, sodium carbonate, hydrochloric acid, aluminium chloride, sodium acetate, 1,1-diphenyl-2-picrylhydrazyl, ethanol, glycerol were purchased from Sigma-Aldrich (Steinheim, Germany), Merck (Darmstadt, Germany) and AlfaAesar (Karlsruhe, Germany).

Determination of polyphenolic contents and antioxidant activity

Quantitative determinations of flavonoids, caffeic acid derivatives and total polyphenolic compounds (TPC) were carried out using spectrophotometric methods. The results were expressed as $\mathrm{mg}$ rutin (RE), mg caffeic acid (CAE), and mg gallic acid equivalents (GAE) per $\mathrm{g}$ dry plant material, as 
FARMACIA, 2020, Vol. 68, 1

previously reported [4, 11, 22, 23]. The samples were evaluated for the antioxidant capacity using the in vitro DPPH. scavenging activity assay (I\%) and ferric reducing antioxidant power (FRAP) assay based on the spectrophotometric methods [1, 2, 4, 6, 21]. DPPH Free Radical Method. The free radical scavenging activity of the red pomace and canes extracts was analysed by using DPPH assay as described earlier, with some modifications [1, 2, 4, 6, 16, 21]. Briefly, $30 \mu \mathrm{L}$ of each extract was mixed with $2 \mathrm{~mL}$ of methanolic DPPH solution $(0.1 \mathrm{~g} / \mathrm{L})$. After reaction for $30 \mathrm{~min}$. at $40^{\circ} \mathrm{C}$ in a thermostatic bath, the absorbance values of the sample were measured at $517 \mathrm{~nm}$ and calculated as a percentage of radical scavenging activities:

$$
\mathrm{I} \%=\left(\mathrm{A}_{\text {control }}-\mathrm{A}_{\text {sample }} / \mathrm{A}_{\text {control }}\right) \times 100,
$$

where $\mathrm{A}_{\text {control }}$ is the absorbance of DPPH radical and methanol (containing all reagents except the extracts) and $\mathrm{A}_{\text {sample }}$ is the absorbance of DPPH radical and extract mixture.

Ferric Reducing Antioxidant Power (FRAP) Assay The ferric reducing/antioxidant power (FRAP) method relies on the change in the colour of a complex with $\mathrm{Fe}^{3+}$ ion of the TPTZ radical by the reduction of the ferric ion to $\mathrm{Fe}^{2+}$-tripyridyltriazine formed by the action of electron donating antioxidants at low $\mathrm{pH}$. $[6,16,21] 6 \mathrm{~mL}$ the FRAP reagent were added to $0.4 \mathrm{~mL}$ of diluted sample following by the absorbance value measurement. A blank solution was prepared likewise by using water instead of the sample. Trolox was used as a reference standard and the calibration curve $\left(R^{2}=0.992\right)$ was registered at $450 \mathrm{~nm}$ using 10 - $40 \mathrm{mg} / \mathrm{L}$ Trolox standard. The results were converted to $\mu$ moles of Trolox equivalents/g dry plant material.

Statistical Analysis. The samples were analysed in triplicate; the mean values and standard deviation were calculated using Microsoft Excel Software.

\section{Results and Discussion}

\section{Extracts Characterization}

The polyphenolic contents are shown in Tables II and III. Concerning the content of flavonoids, the
EH50, EC50 and EH70 extracts of CSP and FNP were richer than the other types of extracts and samples. Similar results to ours were obtained by other authors for the red pomace of Pinot Noir [9]. The amounts of caffeic acid derivatives were highest in the four $50 \%$ and $70 \%$ ethanolic extracts of CSP (on average $18.5 \mathrm{mg} \mathrm{CAE} / \mathrm{g}$ ), followed by the MP, FNP and FNC (with close values). The levels of TPC decreased generally in the order: CSP $>$ FNP $>$ MP > FNC; the highest quantities were detected in all ethanolic samples obtained by hot extraction (between 14 and $41 \mathrm{mg} / \mathrm{g})$. The extract EH50 of CSP contained the highest amount of TPC $(40.52 \mathrm{mg} / \mathrm{g})$. Our results are consistent with those reported by other authors $[12,14,17]$. The polyphenolic content of pomace may differ significantly depending mainly upon variety and the harvest period, as well as the degree of maturity or the technology applied during the vinification. All aqueous extracts contained small amounts of polyphenols (under $9.5 \mathrm{mg} / \mathrm{g}$ ), thereby, distilled water was not a suitable solvent for the extraction of these active principles.

The antioxidant potential was determined by DPPH method and FRAP assay (Table III, Figure 1, Figure 2 ). The antioxidant capacity (I\%) values revealed an important antioxidant activity of the grape pomace. The I (\%) values of the extracts decreased in the following order: CSP $>$ FNP $>$ MP $>$ FNC. Generally, pomace ethanolic extracts showed a significant antioxidant activity. These results are similar to those reported by other authors for Vitis vinifera pomace [12]. The highest radical scavenging activity was showed by the glycerine macerate of CSP (I\% = 72.43), followed by ethanolic extracts (EH50) of CSP and FNP (I\%: $63.25 ; 62.48)$. Lower values were obtained for the FNC extracts (under 50\%). In the present study, the direct relationship between the phenolic content and the antioxidant activity of the extracts was not obvious, observation also reported by other authors. The antioxidant activity could also be altered by effects caused by interactions of polyphenolic principles and the presence of other (non-phenolic) compounds [14].

Flavonoid (mg RE/g) and caffeic acid derivatives ( $\mathrm{mg} \mathrm{CAE} / \mathrm{g}$ ) content in the extracts

\begin{tabular}{|c|c|c|c|c|c|c|c|c|}
\hline & \multicolumn{2}{|c|}{ MP } & \multicolumn{2}{|c|}{ CSP } & \multicolumn{2}{|c|}{ FNP } & \multicolumn{2}{|c|}{ FNC } \\
\hline & $\begin{array}{c}\mathrm{mg} \mathrm{RE} / \mathrm{g} \\
( \pm \mathrm{SD})\end{array}$ & $\begin{array}{c}\mathrm{mg} \mathrm{CAE} / \mathrm{g} \\
( \pm \mathrm{SD})\end{array}$ & $\begin{array}{c}\mathrm{mg} \mathrm{RE} / \mathrm{g} \\
( \pm \mathrm{SD})\end{array}$ & $\begin{array}{c}\mathrm{mg} \mathrm{CAE} / \mathrm{g} \\
( \pm \mathrm{SD})\end{array}$ & $\begin{array}{c}\mathrm{mg} \mathrm{RE} / \mathrm{g} \\
( \pm \mathrm{SD})\end{array}$ & $\begin{array}{c}\mathrm{Mg} \mathrm{CAE} / \mathrm{g} \\
( \pm \mathrm{SD})\end{array}$ & $\begin{array}{c}\mathrm{mg} \mathrm{RE} / \mathrm{g} \\
( \pm \mathrm{SD})\end{array}$ & $\begin{array}{c}\text { mg CAE/g } \\
( \pm \mathrm{SD})\end{array}$ \\
\hline WH & $0.26 \pm 0.03$ & $2.08 \pm 0.42$ & $0.41 \pm 0.01$ & $5.47 \pm 0.42$ & $0.67 \pm 0.04$ & $3.34 \pm 0.26$ & $0.09 \pm 0.005$ & $3.50 \pm 0.28$ \\
\hline WU & $.07 \pm 0.01$ & $0.25 \pm 0.05$ & $0.05 \pm 0.01$ & $0.87 \pm 0.10$ & $0.02 \pm 0.001$ & $0.15 \pm 0.01$ & $0.06 \pm 0.01$ & $1.16 \pm 0.09$ \\
\hline EH50 & 0.17 & $14.7 \pm 0.42$ & 0.22 & $20.80=$ & 15 & $15.00=$ & 20 & 0.44 \\
\hline EU50 & $.72 \pm 0.28$ & $4.15 \pm 0.30$ & 0.04 & $8.78 \pm 0.67$ & 0.16 & $4.12 \pm 0.30$ & $=0.01$ & 4.52 \\
\hline EC50 & $.75 \pm 0.22$ & $12.79 \pm 0.71$ & $1.82 \pm 0.19$ & 18.11 & & $8.05 \pm 0.7$ & $0.35 \pm 0.01$ & 7.59 \\
\hline EH70 & $0.65 \pm 0.35$ & $13.20 \pm 0.8$ & $2.15 \pm 0.03$ & 19.25 & 12 & $17.06 \pm 0.74$ & $.27 \pm 0.03$ & 0.69 \\
\hline EU70 & $0.05 \pm 0.01$ & $2.82 \pm 0.18$ & $0.93 \pm 0.11$ & $8.91 \pm 0.19$ & $37 \pm 0.03$ & $3.01 \pm 0.11$ & $0.08 \pm 0.008$ & 0.15 \\
\hline EC70 & 0.26 & $5.45 \pm 0.43$ & 0.20 & 16.2 & & 8.5 & 0.08 & .60 \\
\hline $\mathrm{M}$ & $28 \pm 0.02$ & $4.32 \pm 0.68$ & $0.49 \pm 0.05$ & $15.50 \pm 0.39$ & $0.29 \pm 0.01$ & $6.92 \pm 0.08$ & $0.02 \pm 0.01$ & $3.86 \pm 0.14$ \\
\hline
\end{tabular}

Each value is the mean of three independent measurements. RE: rutin equivalents; CAE: caffeic acid equivalents. 
Total polyphenolic contents (mg GAE/g) and antioxidant activity (I\%, $\mu \mathrm{M} \mathrm{TE} / \mathrm{g}$ ) of the extracts

\begin{tabular}{|c|c|c|c|c|c|c|c|c|c|c|c|c|}
\hline & \multicolumn{3}{|c|}{ MP } & \multicolumn{3}{|c|}{ CSP } & \multicolumn{3}{|c|}{ FNP } & \multicolumn{3}{|c|}{ FNC } \\
\hline & $\begin{array}{c}\mathrm{TPC} \\
\mathrm{mg} \\
\mathrm{GAE} / \mathrm{g} \\
( \pm \mathrm{SD})\end{array}$ & $\mathrm{I} \%$ & $\begin{array}{c}\text { FRAP } \\
\mu \mathrm{M} \\
\mathrm{TE} / \mathrm{g} \\
( \pm \mathrm{SD})\end{array}$ & $\begin{array}{c}\mathrm{TPC} \\
\mathrm{mg} \\
\mathrm{GAE} / \mathrm{g} \\
( \pm \mathrm{SD})\end{array}$ & $\mathrm{I} \%$ & $\begin{array}{c}\text { FRAP } \\
\mu \mathrm{M} \\
\mathrm{TE} / \mathrm{g} \\
( \pm \mathrm{SD})\end{array}$ & $\begin{array}{c}\text { TPC mg } \\
\text { GAE/g } \\
( \pm S D)\end{array}$ & $\mathrm{I} \%$ & $\begin{array}{c}\text { FRAP } \\
\mu \mathrm{M} \\
\text { TE/g } \\
( \pm \mathrm{SD})\end{array}$ & $\begin{array}{c}\mathrm{TPC} \\
\mathrm{mg} \\
\mathrm{GAE} / \mathrm{g} \\
( \pm \mathrm{SD})\end{array}$ & $\mathrm{I} \%$ & $\begin{array}{c}\text { FRAP } \\
\mu \mathrm{M} \\
\text { TE/g } \\
( \pm \mathrm{SD})\end{array}$ \\
\hline WH & $\begin{array}{c}4.13 \pm \\
0.06 \\
\end{array}$ & $\begin{array}{c}9.79 \pm \\
0.33 \\
\end{array}$ & $\begin{array}{c}440 \pm \\
21 \\
\end{array}$ & $\begin{array}{c}9.46 \pm \\
0.21\end{array}$ & $\begin{array}{c}23.10 \pm \\
0.90 \\
\end{array}$ & $\begin{array}{c}650 \pm \\
18\end{array}$ & & $\begin{array}{c}14.42 \pm \\
1.58\end{array}$ & $\begin{array}{c}524 \pm \\
14\end{array}$ & $\begin{array}{c}7.66 \pm \\
0.22\end{array}$ & $\begin{array}{c}16.97 \pm \\
1.03\end{array}$ & $\begin{array}{c}220 \pm \\
8\end{array}$ \\
\hline WU & $\begin{array}{c}0.45 \pm \\
0.05\end{array}$ & $\begin{array}{c}3.52 \pm \\
0.09\end{array}$ & $320 \pm 5$ & $\begin{array}{c}1.25 \pm \\
0.04\end{array}$ & $\begin{array}{c}7.17 \pm \\
0.08\end{array}$ & $\begin{array}{c}761 \pm \\
38\end{array}$ & $\begin{array}{c}0.23 \pm \\
0.01\end{array}$ & $\begin{array}{c}2.52 \pm \\
0.14\end{array}$ & $\begin{array}{c}412 \pm \\
19\end{array}$ & $\begin{array}{c}3.18 \pm \\
0.10\end{array}$ & $\begin{array}{c}6.92 \pm \\
0.59\end{array}$ & $\begin{array}{c}187 \pm \\
8\end{array}$ \\
\hline EH50 & $\begin{array}{c}18.49 \pm \\
1.52 \\
\end{array}$ & $\begin{array}{c}54.93 \pm \\
3.07 \\
\end{array}$ & $\begin{array}{c}1280 \pm \\
34 \\
\end{array}$ & $\begin{array}{c}40.52 \pm \\
2.48 \\
\end{array}$ & $\begin{array}{c}63.25 \pm \\
6.75 \\
\end{array}$ & $\begin{array}{c}1948 \pm \\
19 \\
\end{array}$ & $\begin{array}{c}33.42 \pm \\
1.58 \\
\end{array}$ & $\begin{array}{c}62.48 \pm \\
5.52 \\
\end{array}$ & $\begin{array}{l}1735 \\
\pm 54 \\
\end{array}$ & $\begin{array}{c}17.62 \pm \\
0.38 \\
\end{array}$ & $\begin{array}{c}19.57 \pm \\
2.43 \\
\end{array}$ & $\begin{array}{c}778 \pm \\
12 \\
\end{array}$ \\
\hline EU50 & $\begin{array}{c}7.97 \pm \\
0.07\end{array}$ & $\begin{array}{c}34.75 \pm \\
1.25\end{array}$ & $\begin{array}{c}325 \pm \\
13\end{array}$ & $\begin{array}{c}18.93 \pm \\
2.07\end{array}$ & $\begin{array}{c}31.23 \pm \\
1.77\end{array}$ & $810 \pm 5$ & $\begin{array}{c}8.00 \pm \\
0.36\end{array}$ & $\begin{array}{c}14.75 \pm \\
0.36\end{array}$ & $\begin{array}{c}725 \pm \\
43\end{array}$ & $\begin{array}{c}8.51 \pm \\
0.49\end{array}$ & $\begin{array}{c}14.76 \pm \\
0.24\end{array}$ & $\begin{array}{c}433 \pm \\
7\end{array}$ \\
\hline EC50 & $\begin{array}{c}15.64 \pm \\
0.36\end{array}$ & $\begin{array}{c}26.42 \pm \\
2.58\end{array}$ & $379 \pm 8$ & $\begin{array}{c}26.38 \pm \\
0.74\end{array}$ & $\begin{array}{c}52.06 \pm \\
7.94 \\
\end{array}$ & $\begin{array}{c}1254 \pm \\
13\end{array}$ & $\begin{array}{c}17.65 \pm \\
0.60\end{array}$ & $\begin{array}{c}31.77 \pm \\
2.34\end{array}$ & $\begin{array}{c}879 \pm \\
9\end{array}$ & $\begin{array}{c}12.20 \pm \\
1.30\end{array}$ & $\begin{array}{c}30.86 \pm \\
2.14\end{array}$ & $\begin{array}{c}552 \pm \\
8\end{array}$ \\
\hline EH70 & $\begin{array}{c}16.12 \pm \\
1.13 \\
\end{array}$ & $\begin{array}{c}43.68 \pm \\
3.44 \\
\end{array}$ & $\begin{array}{c}1724 \pm \\
53 \\
\end{array}$ & $\begin{array}{c}30.88 \pm \\
2.12 \\
\end{array}$ & $\begin{array}{c}58.99 \pm \\
6.01 \\
\end{array}$ & $\begin{array}{c}2428 \pm \\
33\end{array}$ & $\begin{array}{c}26.19 \pm \\
1.26 \\
\end{array}$ & $\begin{array}{c}40.86 \pm \\
4.14 \\
\end{array}$ & $\begin{array}{l}2091 \\
\pm 14 \\
\end{array}$ & $\begin{array}{c}13.77 \pm \\
1.23 \\
\end{array}$ & $\begin{array}{c}25.42 \pm \\
2.58 \\
\end{array}$ & $\begin{array}{c}950 \pm \\
11 \\
\end{array}$ \\
\hline EU70 & $\begin{array}{c}5.54 \pm \\
0.47 \\
\end{array}$ & $\begin{array}{c}20.48 \pm \\
1.52 \\
\end{array}$ & $\begin{array}{c}562 \pm \\
18 \\
\end{array}$ & $\begin{array}{c}15.90 \pm \\
0.32 \\
\end{array}$ & $\begin{array}{c}28.38 \pm \\
1.62 \\
\end{array}$ & $423 \pm 7$ & $\begin{array}{c}6.47 \pm \\
0.53 \\
\end{array}$ & $\begin{array}{c}12.25 \pm \\
0.75 \\
\end{array}$ & $\begin{array}{c}512 \pm \\
12 \\
\end{array}$ & $\begin{array}{c}10.69 \pm \\
2.31 \\
\end{array}$ & \begin{tabular}{|c|}
$35.74 \pm$ \\
3.26 \\
\end{tabular} & \begin{tabular}{|c|}
$728 \pm$ \\
7 \\
\end{tabular} \\
\hline EC70 & $\begin{array}{c}9.76 \pm \\
0.31 \\
\end{array}$ & $\begin{array}{c}28.27 \pm \\
4.74 \\
\end{array}$ & $\begin{array}{c}550 \pm \\
11 \\
\end{array}$ & $\begin{array}{c}23.46 \pm \\
1.54 \\
\end{array}$ & $\begin{array}{c}52.10 \pm \\
2.02 \\
\end{array}$ & $\begin{array}{c}1098 \pm \\
13 \\
\end{array}$ & $\begin{array}{c}16.34 \pm \\
1.11 \\
\end{array}$ & $\begin{array}{c}31.93 \pm \\
3.06 \\
\end{array}$ & $\begin{array}{c}825 \pm \\
5 \\
\end{array}$ & $\begin{array}{c}11.26 \pm \\
1.99 \\
\end{array}$ & $\begin{array}{c}20.66 \pm \\
0.34 \\
\end{array}$ & $\begin{array}{c}530 \pm \\
9 \\
\end{array}$ \\
\hline $\mathrm{M}$ & $\begin{array}{c}8.32 \pm \\
1.68 \\
\end{array}$ & $\begin{array}{c}24.57 \pm \\
0.43 \\
\end{array}$ & $318 \pm 7$ & $\begin{array}{c}18.90 \pm \\
0.22 \\
\end{array}$ & $\begin{array}{c}72.43 \pm \\
9.57 \\
\end{array}$ & $\begin{array}{c}1949 \pm \\
22 \\
\end{array}$ & $\begin{array}{c}10.98 \pm \\
1.02 \\
\end{array}$ & $\begin{array}{c}35.09 \pm \\
3.36 \\
\end{array}$ & $\begin{array}{c}538 \pm \\
12\end{array}$ & $\begin{array}{c}6.36 \pm \\
0.19 \\
\end{array}$ & $\begin{array}{c}24.03 \pm \\
0.97 \\
\end{array}$ & $\begin{array}{c}250 \pm \\
10\end{array}$ \\
\hline
\end{tabular}

Each value is the mean \pm SD of three independent measurements. GAE: Gallic acid equivalents.



Figure 1.

DPPH radical scavenging activity of the extracts

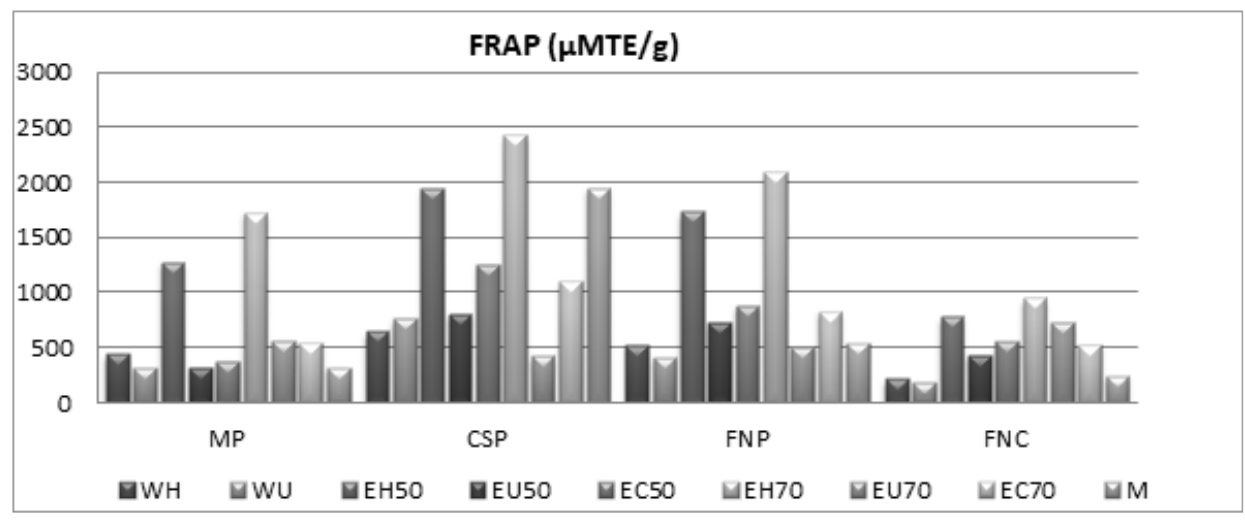

Figure 2.

Antioxidant activity of the extracts measured by FRAP assay

The reduction power of all ethanol extracts on ferric ion is also shown in Table III and Figure 2. FRAP values ranged from 220 to $2425 \mu \mathrm{mol} \mathrm{TE} / \mathrm{g}$. As in the DPPH test, the order was as follows: CSP > FNP > 
FARMACIA, 2020, Vol. 68, 1

MP > FNC, the CSP extracts exhibited the highest antioxidant activity compared to the other samples (Figure 2). The lowest FRAP values were obtained for FNC. Regarding the type of extract, it was observed that the $70 \%$ ethanolic extracts (heat reflux extraction) showed the best antioxidant action, followed by the $50 \%$ ethanolic extracts obtained through the same extraction method. The lowest FRAP values were recorded for the aqueous extracts. In general, the results are consistent with our observations regarding antioxidant power FRAP of the red pomace and canes extracts, with close values reported [16]. Instead, other authors have obtained lower values, up to $880 \mu \mathrm{mol}$ $\mathrm{TE} / \mathrm{g}[10]$.

Comparing the three different pomace varieties, the CSP provided a powerful antioxidant activity, thus offering potential applications in various industrial sectors such as cosmetics.

Experimental design analysis

Extraction performance depends on many process variables as solvent type, extraction method and extraction temperature. Design of experiments is a method that enables the assessment of process parameters over the extracts' quality. It was previously used in extraction methods investigation and optimization. It allows an overall characterisation of the extraction, considering a high number of sometimes interacting variables. In this study the simultaneous variation of the extraction method and ethanol concentration was studied, while other studies performed the optimization of the plant material, the temperature and the ethanol ratio [16].

Since the extracts were meant to be used as actives in cosmetic preparations, the flavonoids content and antioxidant capacity were of interest. Therefore, the flavonoid content, the caffeic acid derivatives content, the gallic acid content and the antioxidant activity were measured. Each of 9 extracts indicated in the design matrix were prepared and tested for the previously mentioned characteristics. In order to analyse the data from the experimental study and model significance, the results were evaluated by means of statistical analysis, using analysis of variance - Anova test (Table IV).

Table IV

Statistical parameters - Anova test

\begin{tabular}{|l|c|c|c|c|}
\hline & $\mathbf{R}^{\mathbf{2}}$ & $\mathbf{Q}^{\mathbf{2}}$ & Reproducibility & $\boldsymbol{p}$ - model \\
\hline mg RE/g & 0.954 & 0.735 & 0.992 & 0.004 \\
\hline mg CAE/g & 0.983 & 0.900 & 0.991 & 0.005 \\
\hline mg GAE/g & 0.998 & 0.816 & 0.999 & 0.000 \\
\hline I\% & 0.996 & 0.948 & 0.995 & 0.000 \\
\hline
\end{tabular}

mg RE/g: flavonoid content; mg CAE/g: caffeic acid derivatives content; mg GAE/g: gallic acid content; I\%: antioxidant activity; $\mathrm{R}^{2}$ : regression coefficient; $\mathrm{Q}^{2}$ : predictive power of the model; $p$ : probability.

Since p-values was lower than 0.05 , all models were significant. Also the results showed a good predictive power, a good reproducibility and a good fit for each of the responses, since the values of these parameters were close to 1 . The mathematical models that indicate the dependence of the responses on the input factors were generated as equations with individual, quadratic and interactive terms. The equations' coefficients encode the type (positive or negative) and the magnitude of the factors' influences and their scaled and centred values are presented in Figure 3.
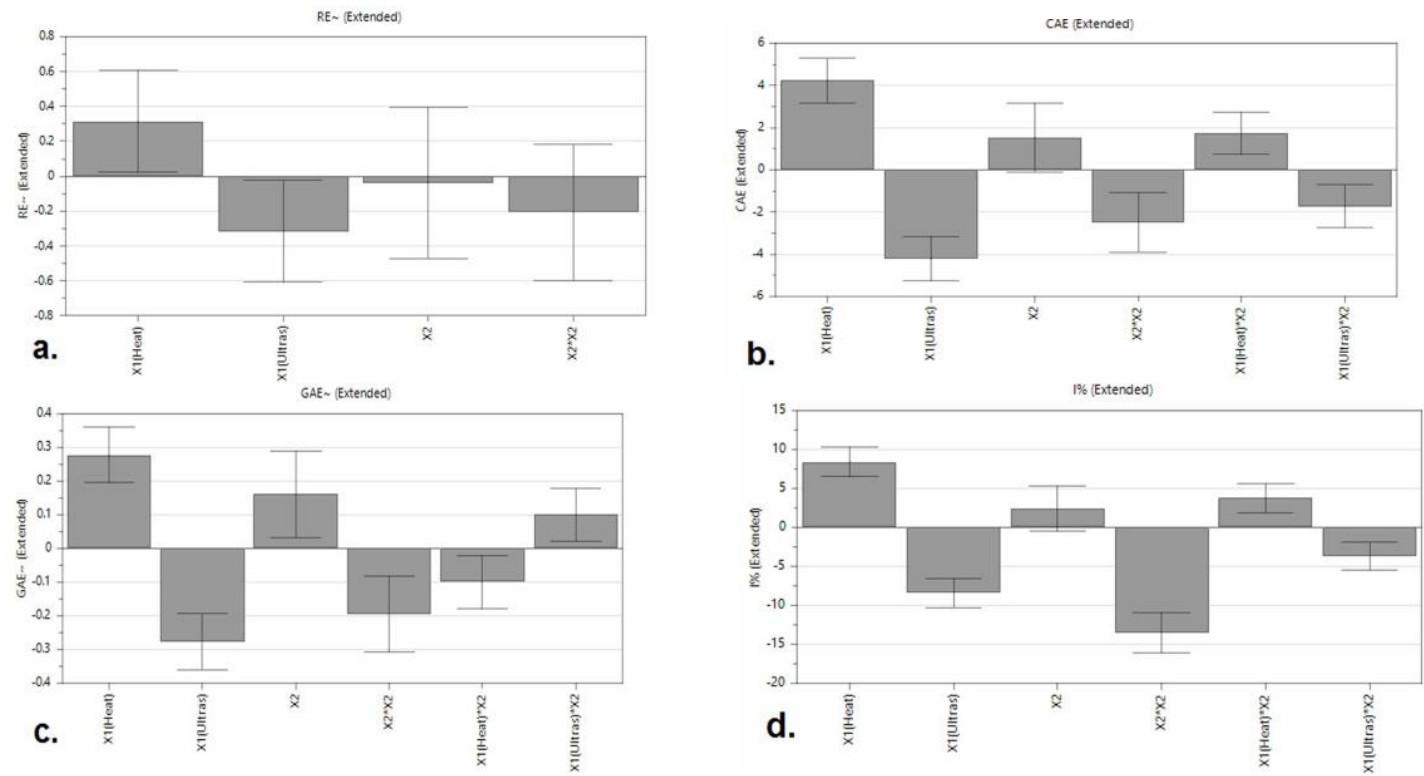

Figure 3.

Scaled and centred coefficients of the models that describe the responses

(a. mg RE/g: flavonoid content; b. mg CAE/g: caffeic acid derivatives content; c. mg GAE/g: total polyphenols content; d. I\%: antioxidant activity; X1 - Extraction method; X2 - Ethanol concentration) 
The screening results showed that the flavonoid content was mainly influenced by the type of extraction method. Heat reflux method has facilitated flavonoid dissolution, while the ultrasonic method yielded lower concentrations. The caffeic acid derivatives were also better extracted with the heat reflux method, compared to the ultrasonication. Although the alcohol concentration was not a statistically significant term, a negative non-linear influence was noticed from the ethanol concentration, which indicates a curved model with an inflexion point. The total polyphenols suffered the same influences form the input variables, except for the interactive effect of the method with the ethanol concentration. While the association of ethanol with heat reflux method favoured the extraction of polyphenols, the ultrasonication had a negative effect on total polyphenols dissolution. These results are in agreement with previously published by our group that showed that intermediate levels of ethanol ratio of $50 \%(\mathrm{v} / \mathrm{v})$, along with the heating treatment led to maximum extraction performance in the experimental domain [16].

\section{Conclusions}

In the present study, the main antioxidant polyphenolic content were determined in the by-products of Vitis vinifera. The results highlight that ethanolic extracts of grape pomace (especially of CSP) obtained by heat reflux, have important antioxidant properties, as well as large polyphenolic compounds content. Our results showed that the pomace of three varieties of wine (Mamaia, Cabernet Sauvignon and Fetească neagră) could be promising sources of different polyphenolic compounds, as valuable raw materials for pharmaceutical or cosmetic industry.

\section{Acknowledgements}

This works was supported by a grant of the Romanian Ministry of Research and Innovation, CCCDI-UEFISCDI, project number PN-III-P1-1.2PCCDI-2017-0251/4PCCDI/2018, within PNCD III

\section{Conflict of interest}

The authors declare no conflict of interest.

\section{References}

1. Andriamadio JH, Rasoanaivo LH, Benedec D, Vlase L, Gheldiu AM, Duma M, Toiu A, Raharisololalao A, Oniga I, HPLC/MS analysis of polyphenols, antioxidant and antimicrobial activities of Artabotrys hildebrandtii O. Hffm. extracts. Nat Prod Res., 2015; 29(23): 2188-2196.

2. Balea SS, Pârvu AE, Pop N, Marín FZ, Andreicuț A, Pârvu M, Phytochemical profiling, antioxidant and cardioprotective properties of Pinot Noir cultivar pomace extracts. Farmacia, 2018; 66(3): 433-441.
3. Belsito M, Hill RA, Klaassen CD, Liebler D, Marks JG, Ronald C, Vitis vinifera (grape) ingredients as used in cosmetics, CIR (Cosmetic Ingredient Review), Washington, DC, 2012: 1-29.

4. Benedec D, Hanganu D, Oniga I, Filip L, Bischin C, Silaghi-Dumitrescu R, Tiperciuc B, Vlase L, Achillea schurii flowers: chemical, antioxidant and antimicrobial investigations. Molecules, 2016; 21(8): 1050: 1-12.

5. Benedec D, Oniga I, Cuibus F, Sevastre B, Stiufiuc G, Duma M, Hanganu D, Iacovita C, Stiufiuc R, Lucaciu $\mathrm{CM}$, Origanum vulgare mediated green synthesis of biocompatible gold nanoparticles simultaneously possessing plasmonic, antioxidant and antimicrobial properties. Int J Nanomed., 2018; 13: 1041-1058.

6. Benzie IFF, Strain JJ, The ferric reducing ability of plasma (FRAP) as a measure of "Antioxidant Power": The FRAP assay. Anal Biochem., 1996; 239: 70-76.

7. Cetin ES, Altinöz D, Tarçan E, Baydar NG, Chemical composition of grape canes. Ind Crops Prod., 2011; 34(1): 994-998.

8. Crişan D, Crişan M, Moldovan M, Lupşor M, Badea R. Ultrasonografic assessement of the cutaneous changes induced by topical flavonoid therapy. Clin Cosmet Investig Dermatol., 2012; 5: 7-13.

9. de Sales NFF, Silva da Costa L, Carneiro TIA, Minuzzo DA, Oliveira FL, Cabral LMC, Torres AG, El-Bacha $\mathrm{T}$, Anthocyanin-rich grape pomace extract (Vitis vinifera $\mathrm{L}$.) from wine industry affects mitochondrial bioenergetics and glucose metabolism in human hepatocarcinoma HepG2 cells. Molecules, 2018; 23(3): pii: E611: 1-17.

10. Gaita C, Alexa E, Popescu I, Popescu S, Negrea M, Poiana MA, Grape pomace: a potential sustainable resource for natural bioactive compounds recovery. J Agroalim Proces Tech., 2017; 23: 141-147.

11. Hanganu D, Filip L, Olah NK, Mocan A, Vlase L, Raita O, Oniga I, Benedec D, Evaluation of polyphenolic profile and antioxidant activity for Cytisus nigricans and Cytisus albus. Farmacia, 2016; 64(6): 863-867.

12. Kabir F, Sultana MS, Kurnianta H, Polyphenolic contents and antioxidant activities of underutilized grape (Vitis vinifera L.) pomace extracts. Prev Nutr Food Sci., 2015; 20(3): 210-214.

13. Katalinic V, Generalic I, Skroza D, Ljubenkov I, Teskera A, Konta I, Boban M, Insight in the phenolic composition and antioxidative properties of Vitis vinifera leaves extracts Croat. J Food Sci Tech., 2009; 1(2): 7-15.

14. Ky I, Lorrain B, Kolbas N, Crozier A, Teissedre PL, Wine by-products: phenolic characterization and antioxidant activity evaluation of grapes and grape pomaces from six different French grape varieties. Molecules, 2014; 19(1): 482-506.

15. Lima Mdos S, Silani Ide S, Toaldo IM, Corrêa LC, Biasoto AC, Pereira GE, Bordignon-Luiz MT, Ninow JL, Phenolic compounds, organic acids and antioxidant activity of grape juices produced from new Brazilian varieties planted in the Northeast Region of Brazil. Food Chem., 2014; 161: 94-103.

16. Moldovan ML, Iurian S, Puscas C, Silaghi-Dumitrescu R, Hanganu D, Bogdan C, Vlase L, Oniga I, Benedec $\mathrm{D}$, A design of experiments strategy to enhance the recovery of polyphenolic compounds from Vitis vinifera 
by-products through heat reflux extraction. Biomolecules, 2019; 9(10): 529: 1-19.

17. Rockenbach II, Gonzaga LV, Rizelio VM, de Souza Schmidt Gonçalves AE, Genovese MI, Fett R, Phenolic compounds and antioxidant activity of seed and skin extracts of red grape (Vitis vinifera and Vitis labrusca) pomace from Brazilian winemaking. Food Res Int., 2011; 44(4): 897-901.

18. Soto ML, Falqué E, Domínguez H, Relevance of natural phenolics from grape and derivative products in the formulation of cosmetics. Cosmetics, 2015: 2(3): 259-276.

19. Sousa EC, Chemical composition and bioactive compounds of grape pomace (Vitis vinifera L.), Benitaka variety, grown in the semiarid region of Northeast Brazil. Int J Toxicol., 2014; 33(3 Suppl): 48S-83S.
20. Teixeira A, Baenas N, Dominguez-Perles R, Barros A, Rosa E, Moreno DA, Garcia-Viguera C, Natural bioactive compounds from winery by-products as health promoters: A review. Int J Mol Sci., 2014; 15(9): 15638-15678.

21. Thaipong K, Boonprakob U, Crosby K, CisnerosZevallos L, Hawkins Byrne D, Comparison of ABTS, DPPH, FRAP, and ORAC assays for estimating antioxidant activity from guava fruit extracts. $J$ Food Compos Anal., 2006; 19(6-7): 669-675.

22. xxx - Farmacopeea Română, ed. a X-a, Ed. Medicală, Bucharest, 1993, (available in Romanian).

23. $\mathrm{xxx}$ - European Pharmacopoeia, $8^{\text {th }}$ edition, Council of Europe, 2014.

24. xxx - European Pharmacopoeia, $9^{\text {th }}$ edition, EDQM, Council of Europe, 2017.

25. $\mathrm{xxx}$ - French Pharmacopoeia, $11^{\text {th }}$ edition, ANSM, 2007. 